\title{
Does clinical examination aid in the diagnosis of urinary tract infections in women? A systematic review and meta-analysis
}

David Medina-Bombardó ${ }^{1,3^{*}}$ and Antoni Jover-Palmer ${ }^{2+}$

\begin{abstract}
Background: Clinicians should be aware of the diagnostic values of various symptoms, signs and antecedents. This information is particularly important in primary care settings, where sophisticated diagnostic approaches are not always feasible. The aim of the study is to determine the probability that various symptoms, signs, antecedents and tests predict urinary tract infection (UTI) in women.

Methods: We conducted a systematic search of the MEDLINE and EMBASE databases to identify articles published in all languages through until December 2008. We particularly focused on studies that examined the diagnostic accuracy of at least one symptom, sign or patient antecedent related to the urinary tract. We included studies where urine culture, a gold standard, was preformed by primary care providers on female subjects aged at least 14 years. A meta-analysis of the likelihood ratio was performed to assess variables related to the urinary tract symptoms.
\end{abstract}

Results: Of the 1, 212 articles identified, 11 met the selection criteria. Dysuria, urgency, nocturia, sexual activity and urgency with dysuria were weak predictors of urinary tract infection, whereas increases in vaginal discharge and suprapubic pain were weak predictors of the absence of infection. Nitrites or leukocytes in the dipstick test are the only findings that clearly favored a diagnosis of UTI.

Conclusions: Clinical findings do not aid in the diagnosis of UTI among women who present with urinary symptoms. Vaginal discharge is a weak indicator of the absence of infection. The urine dipstick test was the most reliable tool for detecting UTI.

\section{Background}

Clinicians should be aware of the diagnostic values of various symptoms, signs and antecedents. This information is particularly important in primary care settings, where sophisticated diagnostic approaches are not always feasible.

Urinary tract infection (UTI) is one of the most common bacterial infections seen in primary care, second only to infections of the respiratory tract $[1,2]$. Infections of the urinary tract can present with various symptoms and signs [3] and are particularly common among women, with an incidence of about $3-9 \%$ in young

\footnotetext{
* Correspondence: dbombardo@gmail.com

† Contributed equally

'Manacor Health Center. Majorca Primary Care Department. Balearic Institute of Health Manacor, Simó Tort s/n, 07500 Manacor, Balearic Islands, Spain Full list of author information is available at the end of the article
}

women [4,5] and $20 \%$ in women aged more than 65 years [6]. Approximately 2.692 of every 100, 000 American individuals were diagnosed with UTIs in the year 2000 [7]. In the United States, UTIs account for $2-3 \%$ of all visits to the general practitioner [8] (i.e., 7-8 million annual visits $[1,9])$ and $2 \%$ of all prescriptions [10]. This results in an annual cost of nearly 1.6 billion dollars $[11,12]$. Sixty-one percent of all UTIs are managed in the primary care setting $[1,13]$.

There is an ongoing debate about the best way to diagnose UTIs in the primary health care setting [14]. This condition is often challenging to diagnose [15] because the clinician has to decide on the proper diagnostic tools and mode of interpretation [16] according to the diagnostic accuracy of clinical findings. Time and resources are scarce for primary health care professionals, whose services are in high demand. Thus, there

\section{Biomed Central}


is a need for studies of the effectiveness of diagnostic and therapeutic tools. A systematic review and metaanalysis of studies on the use of diagnostic tools in primary health care will help identify clinical findings that are useful in the diagnosis of UTIs.

Two meta-analysis $[17,18]$ were performed to determine the usefulness of clinical findings in the diagnosis of UTI. Bent [17] analysis included data from a variety of settings such as hospitals, emergency departments, and specialty clinics. The findings revealed that the prevalence (i.e., a priori probability) of UTI differed depending of the clinical spectrum of patients with UTI. Giesen [18] estimated post-test values of some clinical findings used to diagnose UTI in primary care settings across three different threshold reference standards $\left(10^{2}\right.$ or $10^{3}$ or $\left.10^{5} \mathrm{CFU} / \mathrm{ml}\right)$. We reviewed the accuracy of various symptoms, signs, antecedents and tests performed in the primary care physician's office for the diagnosis of UTI.

\section{Methods}

We conducted a systematic search of the MEDLINE (i. e., literature dating from 1966), and EMBASE (i.e., literature dating from 1974) databases for abstracts of articles published in all languages through December 2008. The selection of publications was made using the following six steps. First, we used an automated system to retrieve abstracts and references that contained the keywords indicated in Table 1. Second, we selected articles whose abstracts were consistent with a previously defined selection protocol. When data in the abstract were insufficient to determine if the article should be included in our study, or when the abstract was not available, the decision to include study was deferred to the next step. Third, we obtained full-text versions of the articles selected in the second step, including articles without abstracts or with insufficient data in the abstracts, and these publications were independently assessed by the two authors using a specific protocol to determine if they should be included in this review. At this step, a secondary review was performed using bibliography of each of the selected articles as a starting point, which included other studies. Fourth, we compared the decisions made by the reviewers during the third step, and discrepancies were discussed until a consensus was attained. Fifth, an external expert assessed those articles for which an agreement had not been reached. The two concordant decisions were those considered for inclusion or exclusion of the study. Sixth, we contacted the authors of articles with missing data or unclear findings to obtain further explanations. If the necessary data were not available, the article was excluded from our study. Table 2 describes the data of all included articles [14,19-28]. Our automated search was complemented by a manual search for papers that were not found in the databases, but that fulfilled our inclusion criteria. These papers were then retrieved using the references of the articles that had been found.

\section{Inclusion criteria}

All articles included in the review provided implicit or explicit evidence obtained from women aged 14 years

Table 1 Keywords used in the automated searches of Medline and EMBASE

\begin{tabular}{|c|c|}
\hline $\begin{array}{l}\text { Search } \\
1\end{array}$ & Parameters defining the type of study: \\
\hline \#1 & $\begin{array}{l}\text { diagnostic OR (diagnostic test) OR (clinical diagnostic) OR (medical diagnosis) OR (physical examinations) OR sensitivity OR specificity OR } \\
\text { (likelihood ratio) OR prediction OR (predictive value) OR (reproducibility of results) OR (Bayes theorem) }\end{array}$ \\
\hline $\begin{array}{l}\text { Search } \\
2\end{array}$ & Parameters defining the study's dependent variable: \\
\hline \#2 & (UTI) OR (urinary tract infection) OR (urinary infection) OR (urinary tract) \\
\hline $\begin{array}{l}\text { Search } \\
3\end{array}$ & Parameters defining the predictive variables studied: \\
\hline \#3 & $\begin{array}{l}\text { (urinary symptoms) OR (physical examination) OR signs OR (clinical history) OR dysuria OR (burning urination) OR (pain urination) OR } \\
\text { (painful urination) OR frequency OR (urinary frequency) OR urgency OR (urinary urgency) OR (nocturnal incontinence) OR (diurnal } \\
\text { incontinence) OR (burning sensation) OR (urinary tenesmus) OR (difficulty micturition) OR (vaginal discharge) OR (vaginal irritation) OR } \\
\text { (genital discomfort) OR (perineal discomfort) OR (lower abdominal discomfort) OR (suprapubic tenderness) OR (hypogastric discomfort) OR } \\
\text { (cold chills) OR (general malaise) OR dyspareunia OR (lumbar tenderness) OR (flank pain) OR (costovertebral angle tenderness) OR (lower } \\
\text { abdominal pain) OR fever OR (genital erythema) OR (genital ulcers) OR (dipstick test) OR (dipstick urinalysis) OR pyuria OR (leukocyte } \\
\text { esterase) OR nitrite OR hematuria OR (recurrent UTI) OR (history of UTI) OR (sexual complaints) OR (sexual activity) OR (diabetes mellitus) } \\
\text { OR urolithiasis OR vulvovaginitis OR (STD) OR (sexually transmitted diseases) OR (urinary catheterization). }\end{array}$ \\
\hline $\begin{array}{l}\text { Search } \\
4\end{array}$ & Parameters defining the setting of the study: \\
\hline \#4 & (primary care) OR (family practice) OR (general practice) OR (family medicine) OR (primary medicine) OR (primary health care). \\
\hline $\begin{array}{l}\text { Search } \\
5\end{array}$ & Finally, the global scheme of the search therefore was including each of 4 searches mentioned above: \\
\hline & \#1 AND \#2 AND \#3 AND \#4 \\
\hline
\end{tabular}


Table 2 Description of studies

\begin{tabular}{|c|c|c|c|c|c|}
\hline $\begin{array}{l}\text { Study/ } \\
\text { Year }\end{array}$ & Design & Participants & Tests and reference & Variables measured & $\begin{array}{c}\text { Prevalence } \\
\text { UTI }\end{array}$ \\
\hline $\begin{array}{l}\text { Verest } \\
\text { LFHM }^{(14)} \\
2000\end{array}$ & prospective & $\begin{array}{c}\text { - } 292 \text { women } \\
\text { suspect of UTI } \\
\text { - age > } 12 \text { yr } \\
\text { - primary care } \\
\text { - excluded if } \\
\text { antibiotic has been } \\
\text { taken } \\
\text { - Netherlands }\end{array}$ & $\begin{array}{l}\text {-dipstick } \\
\text {-culture }\end{array}$ & $\begin{array}{l}\text { - nitrites and leukocytes in dipstick test } \\
\text { (cut-off not defined) } \\
\text { - culture (UTI if } \geq 10^{5} \mathrm{CFU} / \mathrm{mL} \text { ) }\end{array}$ & $\begin{array}{c}p(\text { (UTI) } 58 \% \\
(168 / 292)\end{array}$ \\
\hline $\begin{array}{l}\text { Baerheim } \\
\text { A }^{(19)} \\
1999\end{array}$ & $\begin{array}{l}\text { Prospective } \\
\text { symptoms were } \\
\text { registered in the } \\
\text { patient's home } \\
\text { for three days }\end{array}$ & $\begin{array}{l}\text { - } 196 \text { women with } \\
\text { symptoms of the } \\
\text { lower urinary tract } \\
\text { - age } 48 \text { yr (average) } \\
\text { - primary care } \\
\text { - Norway }\end{array}$ & $\begin{array}{l}\text { - self-monitoring of symptoms } \\
\text { thrice daily for } 3 \text { days } \\
\text { - dipstick test } \\
\text { - culture }\end{array}$ & $\begin{array}{c}\text { - dysuria } \\
\text { - frequency } \\
\text { - urge } \\
\text { - suprapubic pain } \\
\text { - low back pain } \\
\text { - pyuria on dipstick } \\
\text { - culture (UTI if } \geq 10^{5} \mathrm{CFU} / \mathrm{mL} \text { ) }\end{array}$ & $\begin{array}{c}p(U T I)= \\
46.8 \%\end{array}$ \\
\hline $\begin{array}{l}\text { Dawborn } \\
J^{(20)} \\
1973\end{array}$ & prospective & $\begin{array}{c}\text { - } 62 \text { women with } \\
\text { symptoms suggestive } \\
\text { of UTI } \\
\text { - age } 15-50 \text { yr } \\
\text { - primary care } \\
\text { - Victoria (Australia) }\end{array}$ & $\begin{array}{l}\text { - questionnaire for the register of } \\
\text { antecedents, symptoms and signs } \\
\text { - culture }\end{array}$ & $\begin{array}{l}\text { - history of urinary complaints } \\
\text { - pain on micturition } \\
\text { - frequency } \\
\text { - back pain } \\
\text { - anorexia } \\
\text { - vaginal irritation } \\
\text { - abundant vaginal discharge } \\
\text { - culture (UTI if } \geq 10^{5} \mathrm{CFU} / \mathrm{mL} \text { ) }\end{array}$ & $\begin{array}{c}p(U T I)= \\
63 \%(37 / 59)\end{array}$ \\
\hline $\begin{array}{c}\text { Fahey }{ }_{(21)} \\
2003\end{array}$ & Prospective & $\begin{array}{l}\text { - } 136 \text { women with } \\
\text { symptoms for UTI } \\
\text { - age not indicated } \\
\text { - primary care } \\
\text { - United Kingdom }\end{array}$ & $\begin{array}{l}\text { - asked about explicity for } 11 \\
\text { symptoms associated with UTI } \\
\text { - near patient test } \\
\text { - culture }\end{array}$ & $\begin{array}{c}\text { - frquency and dysuria } \\
\text { - dysuria } \\
\text { - fequency } \\
\text { - haematuria } \\
\text { - urgeny } \\
\text { - nocturia } \\
\text { - nauses } \\
\text { - vomiting } \\
\text { - abdominal pain } \\
\text { - back pain } \\
\text { - vaginal discharge } \\
\text { - leukocyte near patient test } \\
\text { - nitrite } \\
\text { - culture (UTI if } \geq 10^{5} \text { CFU/mL) }\end{array}$ & $\begin{array}{c}p(U T I)= \\
38 \%\end{array}$ \\
\hline $\begin{array}{c}\underset{(22)}{\text { Fairley KF }} \\
1971\end{array}$ & prospective & $\begin{array}{l}\text { - } 78 \text { women with } \\
\text { symptomatic } \\
\text { micturition } \\
\text { - age } 8-80 \text { yr, most } \\
30-40 \mathrm{yr} \\
\text { - primary care } \\
\text { - Victoria (Australia) }\end{array}$ & $\begin{array}{l}\text { - symptoms and signs were } \\
\text { registered systematically } \\
\text { - urine culture } \\
\text { - bladder catheterized depending } \\
\text { on culture results }\end{array}$ & $\begin{array}{c}\text { - frequency } \\
\text { - burning } \\
\text { - suprapubic pain } \\
\text { - loin pain } \\
\text { - temperature } \\
\text { - rigors } \\
\text { - nausea and vomiting } \\
\text { - haematuria (microscopy) } \\
\text { - culture (UTI if } \geq 10^{4} \text { bacteria/mL) }\end{array}$ & $\begin{array}{c}p(U T I)= \\
71 \%(55 / 78)\end{array}$ \\
\hline $\begin{array}{l}\text { Jellheden } \\
\text { B }^{(23)} \\
1996\end{array}$ & $\begin{array}{l}\text { systematic } \\
\text { register of clinical } \\
\text { findings from all } \\
\text { patients }\end{array}$ & $\begin{array}{l}\text { - } 819 \text { women with } \\
\text { signs and symptoms } \\
\text { suggesting UTI } \\
\text { - age over } 18 \text { yr } \\
\text { - primary care } \\
\text { - Sweden }\end{array}$ & $\begin{array}{l}\text { - dipstick test } \\
\text { - urinoculture }\end{array}$ & $\begin{array}{c}\text {-dysuria } \\
\text {-frequency } \\
\text {-suprapubic pain } \\
\text {-flank pain } \\
\text {-fever } \\
\text {-nitrites on dipstick } \\
\text { - culture (agar, UTI if } \geq 10^{5} \mathrm{CFU} / \mathrm{mL} \text { ) }\end{array}$ & $\begin{array}{c}p(U T I)= \\
83 \%\end{array}$ \\
\hline $\begin{array}{l}\text { Lawson } \\
\mathrm{DH}^{(24)} \\
1973\end{array}$ & prospective & $\begin{array}{l}\text {-343 women with } \\
\text { symptomatic } \\
\text { micturition } \\
\text { - age 15-55 yr } \\
\text { - Canada }\end{array}$ & $\begin{array}{c}\text { - use of a questionnaire to } \\
\text { register data } \\
\text { - urine sample } \\
\text { - urinoculture } \\
\text { - control of evolution after } 14 \\
\text { days }\end{array}$ & $\begin{array}{c}\text { - pyrexia } \\
\text { - loin pain } \\
\text { - frequency } \\
\text { - dysuria } \\
\text { - nocturia } \\
\text { - stress incontinence } \\
\text { - previous symptoms } \\
\text { - culture }\left(\mathrm{UTI} \text { if } \geq 10^{5} \mathrm{CFU} / \mathrm{mL}\right)\end{array}$ & $\begin{array}{c}p(U T I)= \\
34.3 \%\end{array}$ \\
\hline
\end{tabular}


Table 2 Description of studies (Continued)

\begin{tabular}{|c|c|c|c|c|c|}
\hline $\begin{array}{c}\operatorname{Leibovici~L~}_{(25)} \\
1989\end{array}$ & prospective & $\begin{array}{l}\text { - } 266 \text { women with } \\
\text { dysuria } \\
\text { - } 17 \text { to } 25 \text { years old } \\
\text { - primary care } \\
\text { - Israel }\end{array}$ & $\begin{array}{l}\text { - clinical interview and } \\
\text { examination followed a check-list } \\
\text { - urine sample taken for dipstick } \\
\text { and culture }\end{array}$ & $\begin{array}{c}\text { - sexual activity } \\
\text { - vaginal discharge } \\
\text { - duration of symptoms } \\
\text { - pyuria (sediment) } \\
\text { - hematuria (sediment) } \\
\text { - culture (agar, UTI if } \geq 10^{5} \mathrm{CFU} / \mathrm{mL} \text { ) }\end{array}$ & $\begin{array}{c}\mathrm{p}(\mathrm{UTI})= \\
55.3 \%\end{array}$ \\
\hline $\begin{array}{l}\text { Medina- } \\
\text { Bombardó } \\
\text { D }{ }^{(26)} \\
2003\end{array}$ & prospective & $\begin{array}{l}\text { - } 343 \text { women with } \\
\text { incident urinary } \\
\text { symptoms } \\
\text { - Median age } 44 \\
\text { years old, (range 15- } \\
\text { 90) } \\
\text { - Primary care } \\
\text { - Spain }\end{array}$ & $\begin{array}{l}\text { - clinical systematically interview } \\
\text { and clinical exam by check-list } \\
\text { - urine reactive strip test } \\
\text { - urinoculture }\end{array}$ & $\begin{array}{l}\text { - urinary symptoms: freqúency, burning, } \\
\text { tenesmus, urgency, painfou voiding, } \\
\text { difficult, diurnal and or nocturnal } \\
\text { incontinence and combinations two of } \\
\text { them. } \\
\text { - medical history: urinary tract infections, } \\
\text { sexual activity, vulvovaginitys, urolithiasis, } \\
\text { diabetes mellitus, urinary catheterization } \\
\text { - sings: lower abdominal pain, positive fist } \\
\text { percussion, genital erythema, fever } \\
\text { - accompanying symptoms: lower } \\
\text { abdominal discomfort, general malaise, } \\
\text { genital discomfort, dyspareunia, cold } \\
\text { chills, uncreased vaginal discharge, } \\
\text { perineal discomfort. } \\
\text { - reactive strip test: pyuria, nitrite } \\
\text { - culture (agar, UTI if } \geq 10^{5} \text { CFU/mL) }\end{array}$ & $\begin{array}{c}\mathrm{p}(\mathrm{UTI})= \\
48.4 \%\end{array}$ \\
\hline $\begin{array}{c}\underset{(27)}{\text { Nazareth I }} \\
1993\end{array}$ & prospective & $\begin{array}{l}\text { - } 61 \text { women } \\
\text { presenting with } \\
\text { symptoms on } \\
\text { urination (frequency } \\
\text { or dysuria) } \\
\text { - 16-45 years old } \\
\text { - primary care } \\
\text { - no antibiotic } \\
\text { treatment } \\
\text { - United Kingdom }\end{array}$ & $\begin{array}{c}\text { - data on symptoms, signs and } \\
\text { clinical exam were collected by } \\
\text { the physician using a } \\
\text { questionnaire with open } \\
\text { questions } \\
\text { - urine sample for culture }\end{array}$ & $\begin{array}{c}\text { - dysuria } \\
\text { - frequency } \\
\text { - urgency } \\
\text { - vaginal symptoms } \\
\text { - abdominal symptoms } \\
\text { - back pain } \\
\text { - haematuria } \\
\text { - fever } \\
\text { - culture }\left(\geq 10^{5} \text { CFU/L) }\right.\end{array}$ & $\begin{array}{c}\mathrm{p}(\mathrm{UTI})= \\
28 \%\end{array}$ \\
\hline
\end{tabular}

UTI urinary tract infection; CFU/mL Colony Forming Units/milliliter sample; $p(U T I)$ prevalence of UTI

and older who presented to their primary health care physician with urinary tract complaints of recent onset that had not yet been treated. We included original, observational, prospective, diagnostic studies of the accuracy of clinical findings (i.e., symptoms, signs and antecedents) with regards to the diagnosis of UTI. The studies included consecutive cases of primary care patients in whom UTI was suspected. Review articles and meta-analyses were considered only as sources of references for the original studies. All clinical findings were collected systematically, according to defined standards (i.e., check-list protocol or similar). The variables assessed in the studies were consistent with clinical parameters related to UTI. The cut-off values for urine cultures, our gold standard, were provided (in CFU $/ \mathrm{mL}$ ) for the infecting pathogen, based on usual agar plate urine culture. Data needed to calculate the sensitivity, specificity, and/or likelihood ratio for the predictive value of symptoms, signs, antecedents and/or results of the urine dipstick test was available for all studies included in this report. Finally, the studies included a sufficient period of follow-up to assure that patients' illness is attributable to UTI.

\section{Exclusion criteria}

Studies were excluded from our analysis if the study population included fewer than 50 subjects; a poorly defined population that is, when context, gender, age or study subjects inclusion criteria were not specified in the methods section. When population was recruited from a hospital or a specialty practice, patients younger than 14 years, or patients whose urinary symptoms were not of recent onset (more than one month since onset of symptoms). Studies were also excluded for non-systematic assessment of clinical findings that is, when authors did not describe specifications of materials and methods involved, including how and when measurements were taken. Also were excluded those studies 


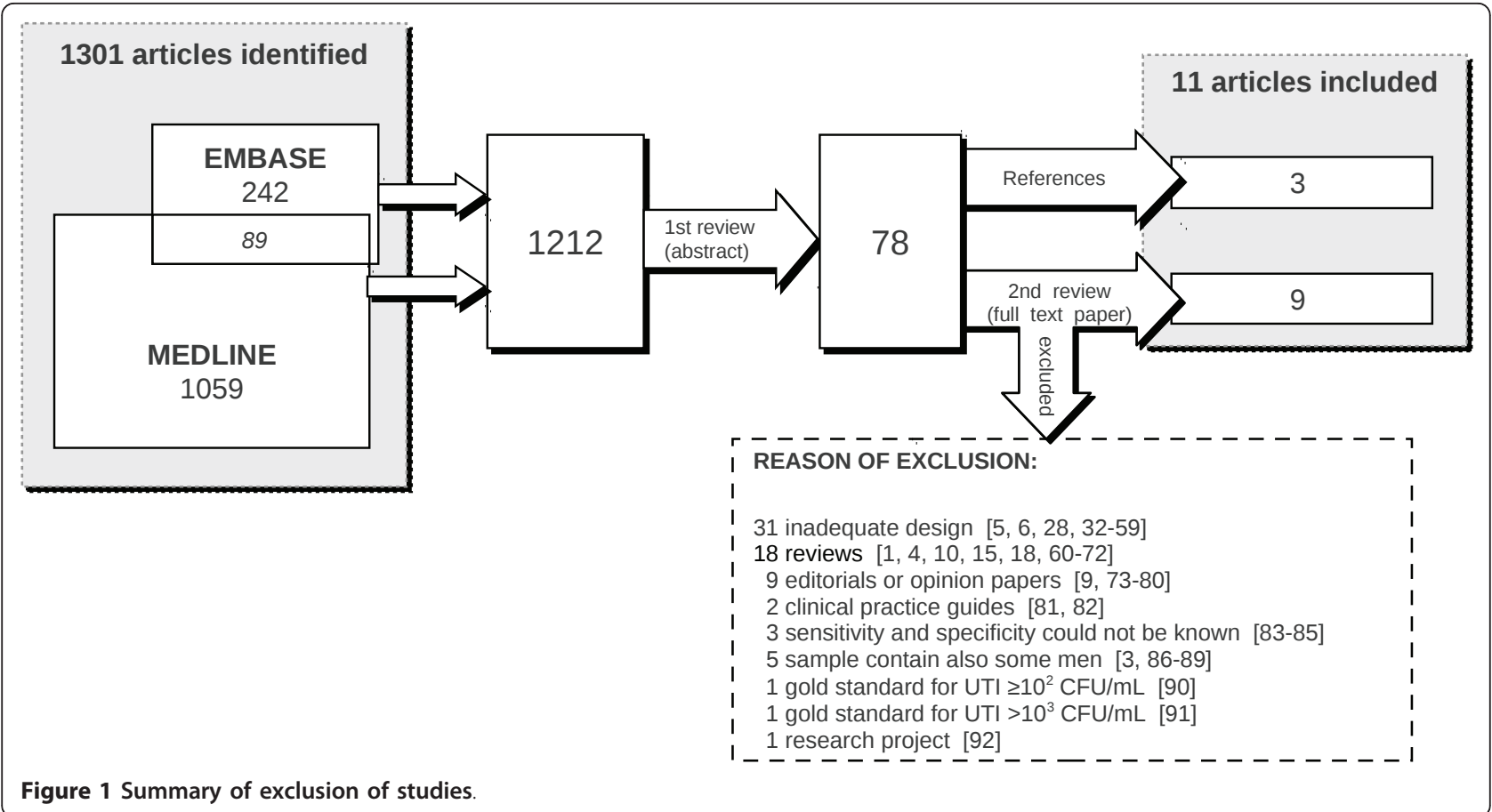

with non-consecutive or non-randomized recruitment of patients into the study, or unoriginal data.

After studies selection we identified that most of studies used as cut off $>10^{5} \mathrm{CFU} / \mathrm{mL}$. In order to avoid heterogeneity of the study population and disease definition as well as statistical power both authors agreed to exclude bacterial count cut off $<10^{5} \mathrm{CFU} / \mathrm{mL}$.

\section{Quality assessment}

The QUADAS assessment tool [29] was applied by one of the reviewers (DMB) in order to evaluate the quality of included studies.

\section{Analysis}

The likelihood ratio (LR) is the ratio of two probabilities, namely the probability that a specific test result is obtained in patients with the disease divided by the probability of a test result in patients without the disease. Positive likelihood ratios (PLRs) are calculated for positive test results and negative likelihood ratios (NLRs) are calculated for negative test results. The diagnostic odds ratio (DOR) describes how well the test works in subjects with disease compared with subjects without disease, as well as the discriminatory properties of positive and negative test results (PLRs and NLRs, respectively). Every clinical exam finding was considered a different test to aid in the diagnosis of urinary tract infections. Sensitivity (S), specificity $(\mathrm{Sp})$, positive and negative likelihood ratios (PLR and NLR) and (DOR), as well as their corresponding standard errors and 95\% confidence intervals $\left(\mathrm{CI}_{95 \%}\right)$, were calculated for every symptom or sign. Results were analyzed for all possible synonyms of each variable, as well as the more commonly used synonyms. Summary or pooled LR (PLRp, NLRp) and pooled DOR (DORp) indices, as well as their corresponding standard errors and $\mathrm{CI}_{95 \%}$, were calculated when two or more studies described the same clinical finding. The statistical heterogeneity of the LR and DOR indices was analyzed. When heterogeneity was found, the threshold effect was analyzed using the Moses-Shapiro-Littenberg method. If heterogeneity could not be explained by the threshold effect, the data were analyzed using a meta-regression model that included prevalence as an independent variable. When the summary likelihood ratio was estimated (i.e., when clinical data were obtained from different studies), heterogeneity was assessed via Chi-square tests and $\mathrm{I}^{2}$ inconsistency tests. Indices were pooled for the fixed effects method, when possible, and heterogeneity was rejected. If heterogeneity or inconsistency could not be explained, the pooled likelihood ratio was interpreted cautiously. The summary LR for random effects is usually recommended for the analysis of accuracy studies when an estimate of between study variation can be incorporated. All statistics were calculated using the Meta-DiSc [30] and RevMan 4.2 [31] software.

\section{Results}

A total of 1, 212 articles were retrieved via an automated search (1, 059 from the MEDLINE database, 242 
from the EMBASE database, 89 found in both databases). We excluded studies of urinary tract treatments, reviews, diagnostic studies performed in pediatric settings, studies including men, editorials, and articles addressing issues other than UTI. Seventy-eight articles were preselected during the initial screening of abstracts.

The second screening (of full-text articles) revealed eight studies $[14,18-23,26,28]$ that satisfied the inclusion criteria. Three additional articles were cited in reviews or in the references of other articles and were subsequently included in our study [24,25,27] (Figure 1). Reasons for exclusion are shown in Figure 1 [1,3-6,9,10,15,18,28,32-92]. We contacted eight authors to obtain missing data $[2,21,23,26,83,85,86,90]$, but only four authors replied [21,23,26,85].

The quality assessment of included studies is presented in Table 3. The index test was not described in sufficient detail to permit replication in all studies included and the reference standard in seven. Blinding of both index test results and reference test was poorly reported in the 10 of the 11 studies considered. In all studies patients received the same reference standard.

We performed a meta-analysis of the studies shown in Table 2 to determine the likelihood ratios (LR) for symptoms such as dysuria, urination frequency, urinary urgency, nocturia, back pain, suprapubic pain, fever, increased vaginal discharge, vaginal irritation, history of UTI, sexual activity and the presence of nitrites or leukocytes in the urine dipstick test, see Table 4. Figures 2, 3 and 4 show the comparative PLRp, NLRp and DORp, respectively, for all clinical findings.

Dysuria, urgency, nocturia, sexual activity and the simultaneous presence of urgency and dysuria were weak diagnostic indicators of UTI. However, an increase in vaginal discharge and suprapubic pain were weak predictors of the absence of infection. Frequency of urination, back pain, fever, vaginal irritation, history of UTI, as well as the simultaneous presence of dysuria with urgency were not significant indicators of UTI. Nitrites or leukocytes in the dipstick test were the only findings that clearly indicated the presence of UTI.

The studies included in our meta-analysis were statistically homogeneous, with regards to the PLRp of all variables except frequency of urination, suprapubic pain, sexual activity and the presence of leukocytes in the urine, as indicated by the dipstick test. NLRp was homogeneous for nine variables (i.e., dysuria, frequency, nocturia, back or suprapubic pain, fever, history of UTI, vaginal irritation and the presence of nitrites in the urine, as indicated by the dipstick test).

The threshold effect can explain LR heterogeneity indexes with regards to urgency, frequency of

Table 3 Quality analysis by QUADAS tool of all studies included

\begin{tabular}{|c|c|c|c|c|c|c|c|c|c|c|c|c|}
\hline & Reference number of studies analysed & & & & & & & & & & & \\
\hline & QUADAS item & {$[14]$} & {$[19]$} & {$[20]$} & {$[21]$} & {$[22]$} & {$[23]$} & {$[24]$} & {$[25]$} & {$[26]$} & {$[27]$} & {$[28]$} \\
\hline 1. & $\begin{array}{l}\text { Was the spectrum of patients representative of the patients who will receive the } \\
\text { test in practice? }\end{array}$ & Y & $Y$ & $Y$ & $Y$ & $U$ & $Y$ & Y & $Y$ & Y & Y & Y \\
\hline 2 & Were selection criteria clearly described? & $U$ & Y & $\mathrm{N}$ & $\mathrm{N}$ & $U$ & $U$ & $\mathrm{~N}$ & Y & Y & Y & $Y$ \\
\hline 3. & Is the reference standard likely to correctly classify the target condition? & Y & Y & Y & Y & Y & Y & Y & Y & Y & Y & Y \\
\hline 4. & $\begin{array}{l}\text { Is the time period between reference standard and index test short enough to be } \\
\text { reasonably sure that the target condition did not change between the two tests? }\end{array}$ & $U$ & $Y$ & $U$ & $U$ & $U$ & $U$ & $Y$ & $U$ & Y & $Y$ & $Y$ \\
\hline 5. & $\begin{array}{l}\text { Did the whole sample or a random selection of the sample, receive verification } \\
\text { using a reference standard of diagnosis? }\end{array}$ & $Y$ & Y & U & Y & Y & Y & Y & Y & $Y$ & $Y$ & Y \\
\hline 6. & Did patients receive the same reference standard regardless of the index test result? & $Y$ & $Y$ & $Y$ & $Y$ & $Y$ & $Y$ & $Y$ & $Y$ & $Y$ & $Y$ & $Y$ \\
\hline 7. & $\begin{array}{l}\text { Was the reference standard independent of the index test (i.e. the index test did } \\
\text { not form part of the reference standard)? }\end{array}$ & $Y$ & $Y$ & $U$ & $U$ & $U$ & $U$ & U & Y & Y & U & $Y$ \\
\hline 8. & $\begin{array}{l}\text { Was the execution of the index test described in sufficient detail to permit } \\
\text { replication of the test? }\end{array}$ & N & $\mathrm{N}$ & N & $\mathrm{N}$ & N & N & $\mathrm{N}$ & N & $\mathrm{N}$ & N & N \\
\hline 9. & $\begin{array}{l}\text { Was the execution of the reference standard described in sufficient detail to permit } \\
\text { its replication? }\end{array}$ & $\mathrm{N}$ & $\mathrm{N}$ & Y & $\mathrm{N}$ & $\mathrm{N}$ & Y & $\mathrm{N}$ & Y & $\mathrm{N}$ & $\mathrm{N}$ & Y \\
\hline 10. & $\begin{array}{l}\text { Were the index test results interpreted without knowledge of the results of the } \\
\text { reference standard? }\end{array}$ & $U$ & $U$ & $U$ & $U$ & $U$ & $U$ & $U$ & $U$ & $Y$ & $U$ & $U$ \\
\hline 11. & $\begin{array}{l}\text { Were the reference standard results interpreted without knowledge of the results of } \\
\text { the index test? }\end{array}$ & $\mathrm{U}$ & $U$ & $U$ & $U$ & $U$ & $U$ & $U$ & $U$ & Y & $U$ & $U$ \\
\hline 12. & $\begin{array}{l}\text { Were the same clinical data available when test results were interpreted as would } \\
\text { be available when the test is used in practice? }\end{array}$ & $Y$ & $Y$ & $Y$ & $Y$ & $Y$ & $Y$ & $Y$ & $Y$ & $Y$ & $Y$ & $Y$ \\
\hline 13. & Were uninterpretable/intermediate test results reported? & $\mathrm{N}$ & N & $\mathrm{N}$ & N & $\mathrm{N}$ & N & $\mathrm{N}$ & N & $\mathrm{N}$ & $\mathrm{N}$ & $\mathrm{N}$ \\
\hline 14. & Were withdrawals from the study explained? & $\mathrm{N}$ & Y & $\mathrm{N}$ & Y & $\mathrm{N}$ & $\mathrm{N}$ & $\mathrm{N}$ & $\mathrm{N}$ & Y & Y & $\mathrm{N}$ \\
\hline
\end{tabular}

$\mathrm{Y}=$ item fulfilled $\mathrm{N}=$ item not fulfiled $\mathrm{U}=$ item unclearly fulfilled 
Table 4 Pooled positive and negative likelihood ratio and diagnostic odds ratio whith theirs $95 \%$ conficence interval, inconsitency index and heterogeneity chisquared significance for all clinical findings analized

\begin{tabular}{|c|c|c|c|c|c|c|c|c|c|c|c|}
\hline $\begin{array}{l}\text { Clinical findings } \\
\text { analized }\end{array}$ & $\begin{array}{l}\text { Number of } \\
\text { studies }\end{array}$ & $\begin{array}{l}\text { Sample } \\
\text { size }\end{array}$ & $\begin{array}{c}\text { Pooled Positive Likelihood } \\
\text { Ratio }\end{array}$ & & & $\begin{array}{c}\text { Pooled Negative Likelihood } \\
\text { Ratio }\end{array}$ & & & $\begin{array}{c}\text { Pooled Diagnostic Odds } \\
\text { Ratio }\end{array}$ & & \\
\hline & & & PLRp $(95 \% \mathrm{Cl})$ & $\% I^{2}$ & $\mathrm{p}\left(\mathrm{Chi}^{2}\right)$ & NLRp $(95 \%$ Cl) & $\% I^{2}$ & $\mathrm{p}\left(\mathrm{Chi}^{2}\right)$ & DORp $(95 \% \mathrm{Cl})$ & $\% \mathrm{I}^{2}$ & $\mathrm{p}\left(\mathrm{Chi}^{2}\right)$ \\
\hline Dysuria & 8 & 1862 & $1.09(1.03-0.16)$ & 41.7 & 0,1 & $0.80(0.68-0.94)$ & 0 & 0,613 & $1,40(1,13-1,73)$ & 0 & 0,470 \\
\hline Frequency & 8 & 1861 & $1.03(0.99-1.08)$ & 63.8 & 0,007 & $0.83(0.65-1.06)$ & 49.3 & 0,055 & $1,25(0,97-1,61)$ & 52,2 & 0,041 \\
\hline Suprapubic pain & 7 & 2409 & $0.81(0.73-0.89)$ & 63.4 & 0,012 & $1.14(1.07-1.21)$ & 40.8 & 0,119 & $0,66(0,56-0,79)$ & 49,7 & 0,064 \\
\hline Back pain & 7 & 1512 & $1.15(0.96-1.37)$ & 26.5 & 0,227 & $0.95(0.90-1.01)$ & 0 & 0,6 & $1,24(0,96-1,59$ & 15,9 & 0,309 \\
\hline History of UTI & 4 & 998 & $1.23(0.99-1.27)$ & 59.3 & 0,061 & $0.89(0.79-1.01)$ & 41.6 & 0,162 & $1,27(1,00-1,60)$ & 52,1 & 0,1 \\
\hline Fever & 4 & 797 & $0.69(0.43-1.11)$ & 36.1 & 0,195 & $1.04(0.99-1.08)$ & 51.9 & 0,101 & $0,65(0,41-1,05)$ & 39,0 & 0,178 \\
\hline Vaginal discharge & 4 & 722 & $0.63(0.49-0.80)$ & 0 & 0,428 & $1.18(1.08-1.28)$ & 78.7 & 0,003 & $0,50(0,36-0,70)$ & 0 & 0,401 \\
\hline Leukocytes * & 4 & 705 & $1.42(1.23-1.57)$ & 87.8 & $<0,001$ & $0.44(0.35-0.56)$ & 0 & 0,516 & $3,58(2,53-5,07)$ & 0 & 0,914 \\
\hline Urgency & 4 & 577 & $1.18(1.04-1.34)$ & 28.3 & 0,242 & $0.75(0.62-0.94)$ & 89.3 & $<0,001$ & $1,61(1,15-2,27)$ & 40,5 & 0,163 \\
\hline Nitrites * & 3 & 626 & $6.51(4.24-10.01)$ & 65.2 & 0,056 & $0.58(0.52-0.64)$ & 58.0 & 0,093 & $11,3(6,95-18,35)$ & 51,6 & 0,126 \\
\hline Dysuria \& urgency ${ }^{\S}$ & 2 & 1149 & $1.53(0,94-2.50)$ & 94.2 & $<0,001$ & $0.44(0.21-0.92)$ & 89.9 & 0,002 & $3,47(1,04-11,62)$ & 92,0 & $<0,001$ \\
\hline Sexual activity ${ }^{\S}$ & 2 & 584 & $1.14(0,90-1.44)$ & 75.0 & 0,05 & $0.66(0.28-1,58)$ & 89.8 & 0,002 & $1,71(0,58-5,05)$ & 87,6 & 0,004 \\
\hline Nocturia & 2 & 415 & $1.28(1.08-1.52)$ & 0 & 0,955 & $0.72(0.57-0.92)$ & 0 & 0,508 & $1,79(1,17-2,69)$ & 0 & 0,777 \\
\hline Vaginal irritation & 2 & 361 & $0.90(0.57-1.42)$ & 36.3 & 0,210 & $1.02(0.94-1.11)$ & 0 & 0,373 & $0,87(0,48-1,59)$ & 17,6 & 0,271 \\
\hline Frequency \& dysuria & 2 & 284 & $1.10(0.98-1.23)$ & 39.3 & 0,199 & $0.67(0.41-1.09)$ & 77.2 & 0,036 & $1,66(0,91-3,02)$ & 72,7 & 0,056 \\
\hline
\end{tabular}

PLRp $(95 \%$ Cl) Pooled Positive Likelihood Ratio and its 95\% confidence interval

NLRp $(95 \%$ Cl) Pooled Negative Likelihood Ratio and its $95 \%$ confidence interval

DORp (95\% Cl) Pooled Diagnostic Odds Ratio and its $95 \%$ confidence interval

$I^{2}$ Inconsitency Index

$\mathrm{p}\left(\mathrm{Chi}^{2}\right)$ heterogeneity chi-squared significance

* Measured by Dipstick test in urine sample

${ }^{\S}$ Index calculated by random effects model (else by fixed effects model) 


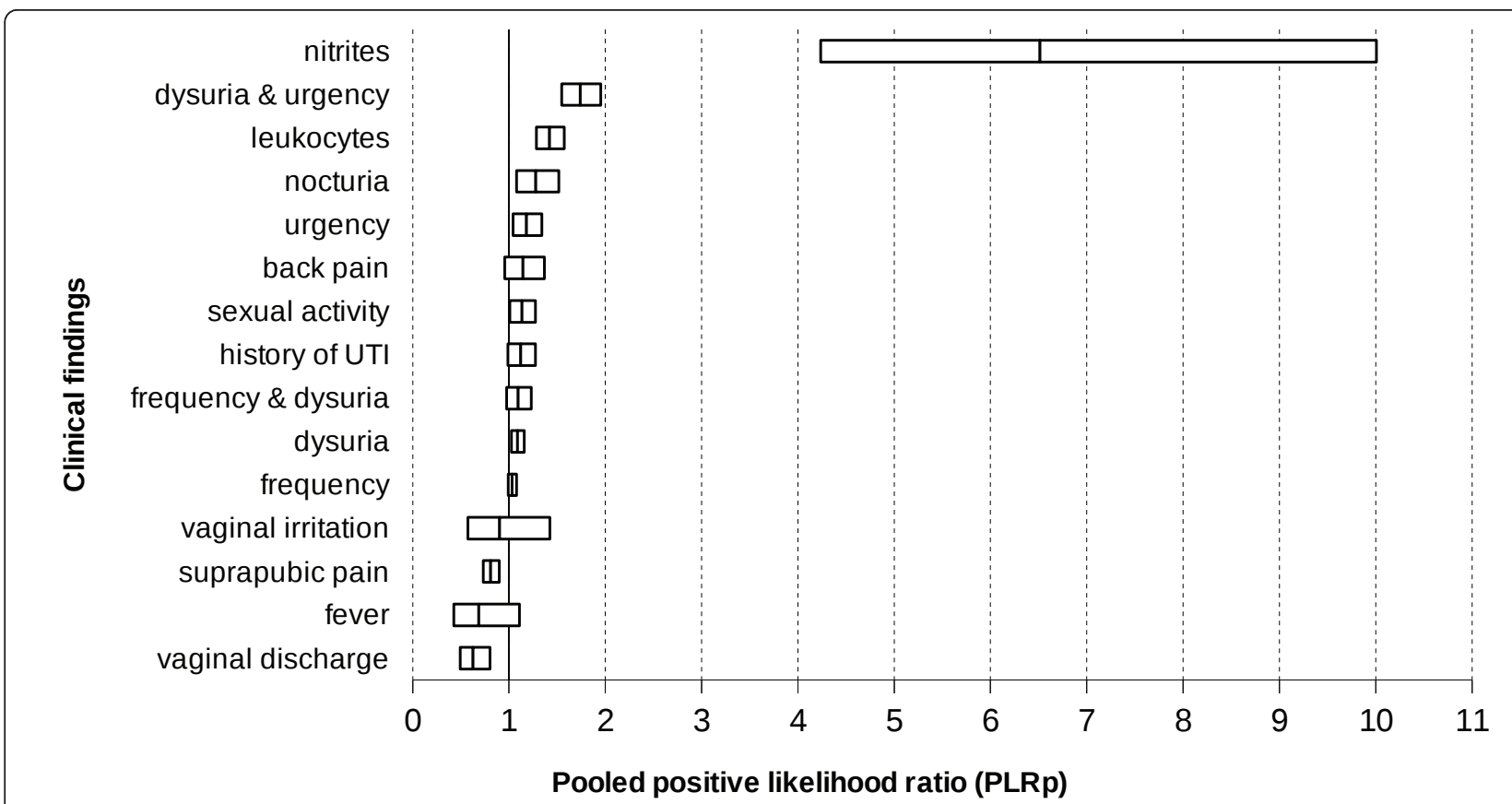

Figure 2 Comparative estimate of the number of times a woman with a urinary tract infection (UTI) is more likely than a woman without a UTI to present with certain clinical findings (i.e., pooled positive likelihood ratios - PLRp - and confidence intervals for all clinical findings).

urination, suprapubic pain, and the presence of leukocytes in the urine, as indicated by the dipstick test. We were unable to analyze threshold effect of data on sexual activity, vaginal irritation, and the simultaneous presence of dysuria with urgency or frequency because only two studies assessed both of these variables. Prevalence was not a source of heterogeneity in the metaregression model.

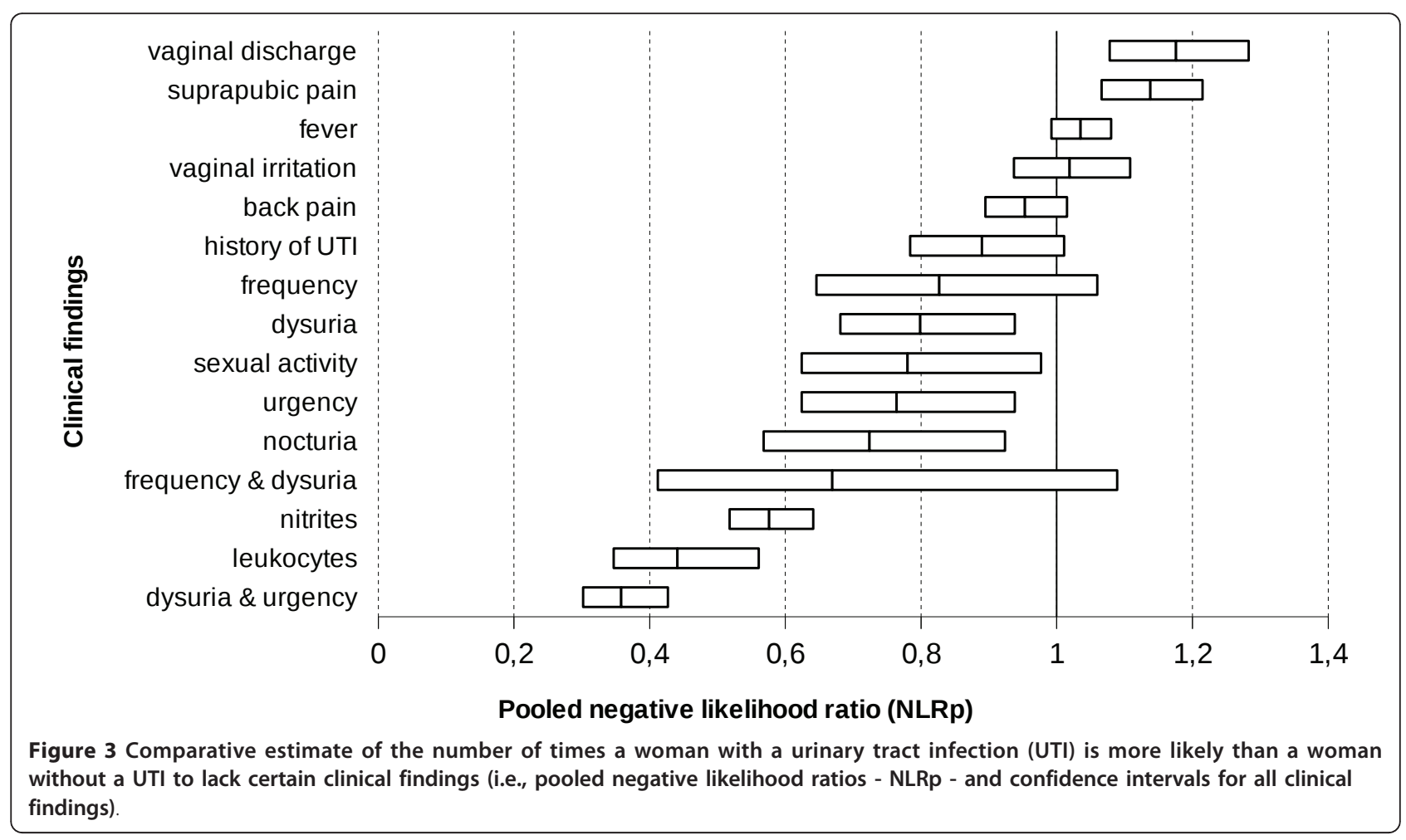




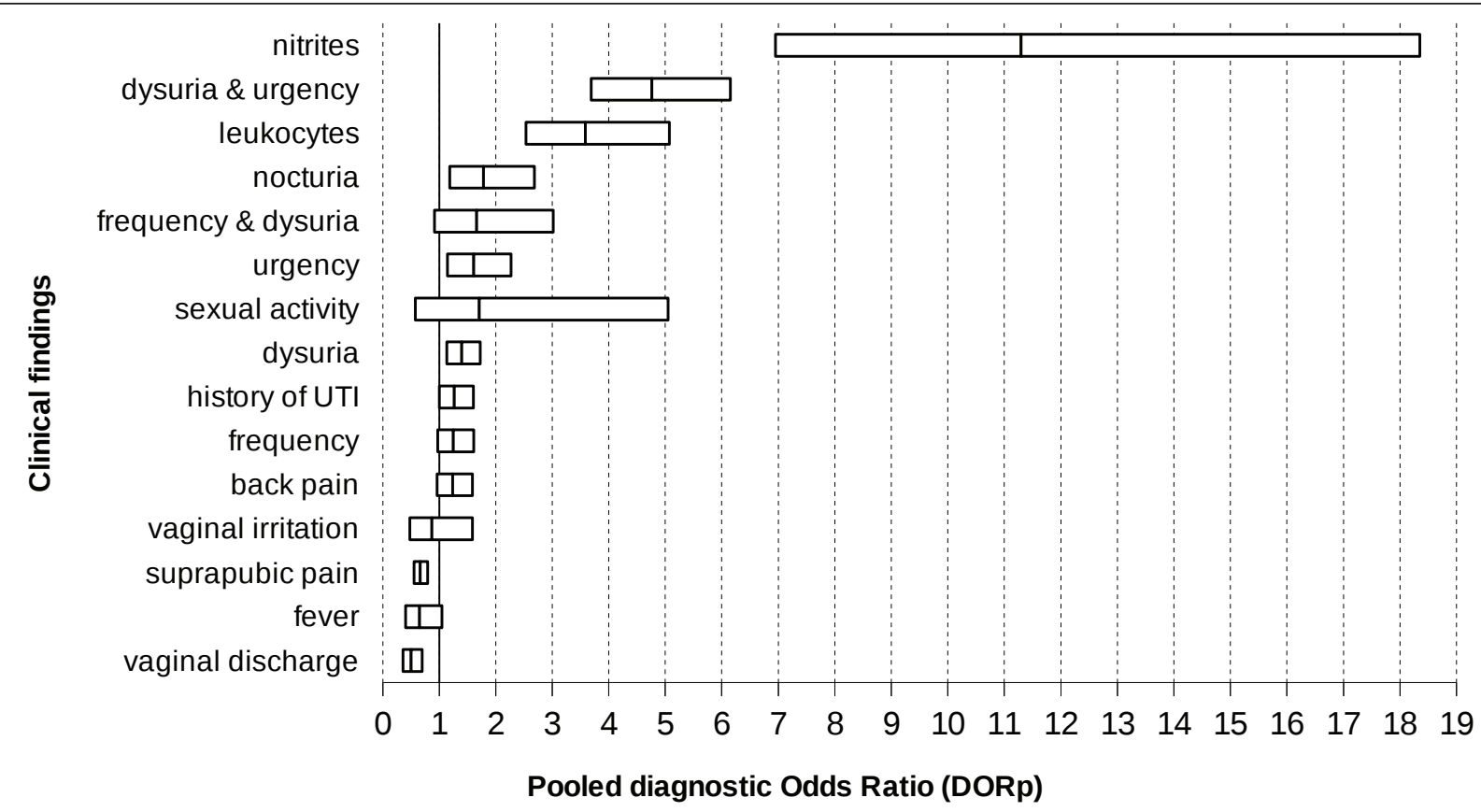

Figure 4 Comparative usefulness of clinical findings in the diagnosis of urinary tract infections. The pooled diagnostic odds ratio (DORp) values estimate the accuracy of the test (i.e., clinical finding) in patients with and without disease, as well as the discriminatory properties of positive and negative test results (PLR and NLR, respectively).

Only two studies studied nocturia (415 cases), vaginal irritation (361 cases), dysuria with frequency (284 cases) or urgency $(1,149$ cases), or sexual intercourse (584), consequently, it was not possible to explore their threshold effect by Moses-Shapiro-Littenberg method. There is also considerable inconsistency among studies with regards to the PLRp and NLRp values for sexual activity $\left(\mathrm{I}^{2}=75.0 \%\right.$ PLRp and $89.8 \%$ NLRp) and for the simultaneous presence of dysuria and urgency (94.2\% PLRp and 89.9\% NLRp). However, there were inconsistencies in the analysis of PLRp in the cases presence of leukocyes (87.8\%), frequency $(63.8 \%)$ and suprapubic pain $(63.4 \%)$, as well as in the analysis of NLRp in the cases of urgency (92.8\%), vaginal discharge $(78.7 \%)$ or the simultaneous presence of dysuria and frequency (77.2\%).

\section{Discussion}

Our results show that exploratory clinical findings may suggest a diagnosis of UTI in women; however, nitrituria is clearly the most useful diagnostic indicator. Some clinical findings, alone or in combination with others, can indicate the presence of UTI. Consistent with the results of a meta-analysis by Bent [17], our results show that dysuria and the presence of nitrites or leukocytes in the urine, as indicated by the dipstick test, are useful in the diagnosis of UTI. Furthermore, increased vaginal discharge indicates the absence of infection. The presence or absence of back pain provides little diagnostic information. However, contrary to our results, Bent [17] found that frequent urination or back pain increased the likelihood of UTI, whereas vaginal irritation was not associated with UTI. Urgency, nocturia, sexual activity and a history of UTI were not considered by Bent, whereas costovertebral angle tenderness was not considered in our study. Contrary to our analysis, Bent calculated separate pooled indexes for back pain and flank pain. Both metaanalyses share several of the above mentioned shortcomings; thus, these results should be interpreted with caution. Bent's meta-analysis [17] included a considerably more heterogeneous population than did our study, but did not include any analysis of heterogeneity. Bent's pooled LR indexes were calculated using a random effects model, whereas ours were calculated using a fixed effects model with corresponding differences in confidence intervals.

On the other hand in Giesen meta-analysis [18] only dysuria and urgency pooled LR were favorable at UTI diagnostic and fever were indifferent as observed in our results, using the same threshold in urinoculture. Other results were not in accordance with our finding. That is, lower abdominal pain PLR and NLR were indiferent in Giesen meta-analisis and PLR favourable and NRL indiferent for us. Giesen's pooled LR indexes conficence intervals were calculated using random effects model and we used fixed effects. 
We would like to emphasize the fact that we analyzed only those variables for which results were found in more than one study. The studies included in our analysis were of adequate quality with regards to all concepts usually assessed $[17,93]$ with the exception of one study that included a sample size of 48 subjects. However, that study met all other quality requirements [20]. Although we may have lost some relevant clinical information by excluding studies with sample sizes less than 50 , we gained statistical precision and our data demonstrated minor variability when the random effects method was applied. In addition, our quality analysis revealed a decrease in heterogeneity.

We included studies that recruited consecutive samples, which is the recommended method [93] to reflect clinical conditions. Randomized samples would be ideal; however, there have not been published studies of diagnostic tests based on randomized samples.

Variability in the results of a diagnostic test can be attributed to several factors. The sensitivity and specificity of a test, as well as the LR, may change during the course of the disease [93-95] as its manifestations become more or less pronounced. Validity test parameters such as sensitivity, specificity and likelihood ratio remain constant only if the test is used on a population with similar characteristics as the subjects whose parameters were originally estimated. However, post-test probability depends on pre-test probability. This may be related to the variability encountered when the same diagnostic tool is used in different levels of health care, a phenomenon known as the referral filter bias [96,97]. This concept is independent of the variability that results from differences in prevalence at one stage of the natural history of the disease $[93,94,96,97]$, and it may also affect the predictive value of the test when used in that context. Therefore, we only included studies performed in the primary care setting. This may partially explain the differences between our results and those reported by Bent [17], whose population was more heterogeneous.

Another source of variability is interobserver variability, due to differences in the understanding of terms and in the examination techniques used by different field researchers. In many instances, variables are not clearly defined (i.e., different names may refer to the same concept, whereas one name may refer to quite different things), making it difficult to understand what the study is attempting to measure. Interobserver variability is a source of potential bias and an important limitation to studies that aim to estimate the validity of diagnostic tools. It is also of particular concern in studies that focus on symptoms. There were no clear definitions of variables in the studies included in our analysis. For example, pain in the lumbar region was variously referred to as back pain [20,21,27], low back pain [18], loin pain $[22,87,88]$, flank pain [23] or kidney/flank pain [90] while other authors [17] have distinguished flank pain from back pain. Fever was referred to as fever [26,27,87,88], pyrexia [24] or temperature [22]. However, for the poorly defined symptom dysuria, the overall PLRp and NLRp values obtained for dysuria $[18,21,23,24,27]$ were $1.06\left(\mathrm{CI}_{95 \%} 1.00-1.13\right)$ and 0.84 $\left(\mathrm{CI}_{95 \%}\right.$ 0.68-1.03), respectively. These findings do not differ greatly from the results obtained when we include some of the terms usually considered synonymous for dysuric syndrome $[98,99]$, such as pain on micturition $[20,26]$ or burning on micturition [22]. The PLRp and NLRp values would then be $1.09\left(\mathrm{CI}_{95 \%} 1.03-1.16\right)$ and $0.80\left(\mathrm{CI}_{95 \%}\right.$ 0.68-0.94), respectively.

The evidence power analysis further revealed homogeneous DORp values for urgency, vaginal discharge, leukocytes in the urine, and simultaneous dysuria and frequency. However, the DORp values were heterogeneous for frequency, sexual activity and simultaneous dysuria and urgency. In all cases, the threshold effect could be explained by heterogeneity, except for history of UTI. We included studies that showed wide differences in the pre-test probability of UTI (i.e., range: $28 \%$ [27] to $83 \%$ [23]) because the target populations in all of these studies were similar (i.e., primary care patients). An unknown factor might explain these differences, but pre-test probability could not account for the heterogeneity observed in a metaregression model. The available data do not allow us to classify our results according to age for the comparison of the pre-test probabilities of UTI [7,100-102]. Poor descriptions of methods and incomplete data made it difficult to assess the methodological quality of the studies included in our analysis, to compare our inclusion and exclusion criteria, and to identify and control for other characteristics that may not have been reflected in the publication. The validity of our meta-analysis is limited by quality analysis of selected studies. Our most important limitations are the poor definition of the index test, which is clinical symptoms and signs, in all studies. Furthermore, unclear specification of blind interpretation of the index test or reference standard results. Consensus tools like QUADAS $[29,103]$ are needed to assess the quality of studies included in meta-analysis such as this and necessary to performing diagnostic test studies designs. Therefore, it is difficult to exclude the possibility of work-up bias, diagnostic-review bias, test-review bias or incorporation bias [104], all of which could have influenced the selection or classification bias of the studies included in our analysis. Moreover, these problems limit our capacity to detect a bias that is particularly difficult to control in systematic reviews of diagnostic tests; namely, publication bias $[105,106]$. However, the existence of 
publication bias can be suspected. An interesting project [92] promises to assess the validity of clinical findings and improve their use in diagnosing UTI.

\section{Conclusions}

\section{Implications for practice}

Clinical findings are not 'per se' predictive of UTI. In women who present to their primary care provider with urinary symptoms, an office urine dipstick test could be helpful to guide UTI diagnosis, and identification of nitrites or leukocytes is a good predictor of UTI.

\section{Implications for research}

The quality of meta-analyses and systematic reviews of diagnostic tests could be improved by the development of consensus tools. These tools would aid in the design of better studies and in the analysis of clinical findings, which would ultimately improve the diagnosis of UTI.

\begin{abstract}
Acknowledgements
The authors are grateful to Xavier Bonfill Gosp MD, PhD; Magdalena Esteva Cantó MD, PhD; Maria Ramos Monserrat MD, PhD; Carlos. Campillo Artero MD, PhD; Francisco Campoamor Landín MD and Victor Abraira Santos MD, $\mathrm{PhD}$; for their helpful insights in critically revising and the manuscript for important intellectual content, but does not meet criteria for authorship. A portion of this study was completed as part of the first author's PhD dissertation at the Universitat Autònoma de Barcelona under XBG direction. This research was funded by an Evidence-Based Healthcare (ASBE) grant awarded by the Iberoamerican Cochrane Center at Universitat Autònoma de Barcelona. This study was also supported by the University Institute of Health Sciences and by the Preventive Activities and Health Promotion Network grant RD06/0018/0036 of the Ministry of Health and Social Participation.
\end{abstract}

\section{Author details \\ ${ }^{1}$ Manacor Health Center. Majorca Primary Care Department. Balearic Institute of Health Manacor, Simó Tort s/n, 07500 Manacor, Balearic Islands, Spain. ${ }^{2}$ Arquitecte Bennasar Health Center, Majorca Primary Care Department. Balearic Institute of Health, Avda Gaspar Bennàzar 9, 07004 Palma, Balearic Islands, Spain. ${ }^{3}$ Unit of Reseach, Majorca Primary Care Department. Balearic Institute of Health, Reina Esclaramunda 9, 07003 Palma, Balearic Islands, Spain.}

\section{Authors' contributions}

DMB participated in the coordination and design of the study, in search, review and selection of articles, perfomed the statistical analysis and drafted the manuscript. AJP participated in the design of the study, in review an selection of articles and helped to draft the manuscript. Both authors read and approved the final manuscript.

\section{Competing interests}

The authors declare that they have no competing interests.

Received: 26 August 2010 Accepted: 10 October 2011 Published: 10 October 2011

\section{References}

1. Burt CW, Schappert SM: Ambulatory care visits to physician offices, hospital outpatient departments, and emergency departments: United States, 1999-2000. Vital Health Stat 13 2004, , 157: 1-70.

2. Pallares J, Casas J, Guarga A, Marquet R, Grifell E, Juve R, Castelltort R: Rapid diagnostic methods as predictors of urinary infection in primary health care. Med Clin (Barc) 1988, 91(20):775-778.
3. Berg AO, Soman MP: Lower genitourinary infections in women. J Fam Pract 1986, 23(1):61-67.

4. Harper J: Managing UTI in adults. Practitioner 2000, 244(1610):464-467, 469-471.

5. Winkens RA, Leffers P, Trienekens TA, Stobberingh EE: The validity of urine examination for urinary tract infections in daily practice. Fam Pract 1995 , 12(3):290-293.

6. Bertakis $\mathrm{KD}$, Ross $\mathrm{JL}$ : Office evaluation of urinary tract infections in elderly women. J Fam Pract 1987, 15(3):427-429.

7. Griebling TL: Urologic Diseases in America Project: Trends in Resource Use for Urinary tract Infections in Women. J Urol 2003, 173:1281-1287.

8. Brooks D: The management of suspected urinary tract infection in general practice. Br J Gen Pract 1990, 40(339):399-402.

9. Schappert SM: National Ambulatory Medical Care Survey: 1992 Summary. Advance Data from vital and health statistics; 94-253. Hyattsville, Maryland: NCHS; 1994

10. Fenwick EA, Briggs $\mathrm{AH}$, Hawke $\mathrm{Cl}$ : Management of urinary tract infection in general practice: a cost-effectiveness analysis. Br J Gen Pract 2000, 50(457):635-639.

11. Foxman B, Barlow R, D'Arcy H, Gillespie B, Sobel JD: Urinary tract infection: self-reported incidence and associated costs. Ann Epidemio 2000, 10(8):509-515.

12. Litwin MS, Saigal CS, Yano EM, Avila C, Geshwind SA, Hanley JM, Joyce GF, Madison R, The Urologic Diseases in America Project: Urologic Diseases in America Project: Analytical Methods and Principal Findings. J Urol 2005, 173:933-937.

13. Woodwell DA, Cherry DK: National Ambulatory Medical Care Survey: 2002 summary. Adv Data 2004, , 346: 1-44.

14. Verest LFHM, Van Esch WMJ, Van Ree JW, Stombberingh EE: Management of acute uncomplicated urinay tract infections in general practice in the south of the Netherlands. Br J Gen Pract 2000, 50:305-310.

15. Grob PR: Urinary tract infection in general practice. Practical problems. Practitioner 1978, 221(1322):237-241.

16. Irwig L, Tosteson ANA, Gatsonis C, Lau J, Colditz G, Chalmers TC, Mosteller F: Guidelines for Meta-analyses Evaluating Diagnostic Test. Ann Intern Med 1994, 120(8):667-676.

17. Bent S, Saint S: The optimal use of diagnostic testing in women with acute uncomplicated cystitis. Am J Med 2002, 113(1S):20-28.

18. Giesen LG, Cousins G, Dimitrov BD, van de Laar FA, Fahey T: Predicting acute uncomplicated urinary tract infection in women: a systematic review of the diagnostic accuracy of symptoms and signs. BMC Fam Pract 2010, 11:78.

19. Baerheim A, Digranes A, Hunskaar S: Equal symptomatic outcome after antibacterial treatment of acute lower urinary tract infection and the acute urethral syndrome in adult women. Scand J Prim Health Care 1999, 17(3):170-173.

20. Dawborn JK, Page M, Schiavone DJ, Semmens K, Smyth JL: Urinary infection in general practice. Diagnosis and treatment. Med J Aust 1973, 1(18):885-890.

21. Fahey T, Webb E, Montgomery AA, Heyderman RS: Clinical management of urinary tract infection in women: a prospective cohort study. Fam Pract 2003, 20:1-6.

22. Fairley KF, Carson NE, Gutch RC, Leighton P, Grounds AD, Laird EC, McCallum PH, Sleeman RL, O'Keefe CM: Site infection in acute urinary tract infection in general practice. Lancet 1971, 2(7725):615-618.

23. Jellheden B, Norrby RS, Sandberg T: Symptomatic urinary tract infection in women in primary health care. Bacteriological, clinical and diagnostic aspects in relation to host response to infection. Scand J Prim Health Care 1996, 14(2):122-128.

24. Lawson DH, Clarke A, McFarlane DB, McAllister, Linton AL: Urinary tract symptomatology in general practice. J Royal Col Gen Pract 1973, 23:548-555.

25. Leibovici L, Alpert G, Laor A, Kalter-Leibovici O, Danon YL: A clinical model for diagnosis of urinary tract infection in youg women. Arch Intern Med 1989, 149:2048-2050.

26. Medina-Bombardó D, Segui-Díaz M, Roca-Fusalba C, Llobera J, dysuria team: What is the predictive value of urinary symptoms for diagnosing urinary tract infection in women? Fam Pract 2003, 20(2):103-107, Corrigendum Fam Pract 2003, 20(3):619-621. 
27. Nazareth I, King M: Decision Making by General Practitioners i Diagnosis and Management of Lower Urinary Tract Symptoms in Women. BMJ 1993, 306(6885):1103-1106.

28. Osterberg E, Aspevall O, Grillner L, Persson E: Young women with symptoms of urinary tract infection. Prevalence and diagnosis of chlamydial infection and evaluation of rapid screening of bacteriuria. Scand J Prim Health Care 1996, 14(1):43-49.

29. Whiting P, Rutjes AWS, Reitsma JB, Bossuyt PM, Kleijnen J: The development of QUADAS: a tool for the quality assessment of studies of diagnostic accuracy included in systematic reviews. BMC Med Res Methodol 2003, 3:25.

30. Zamora J, Muriel A, Abraira V: Meta-DiSc for Windows: A Software package for the Meta-analysis of Diagnostic Tests. XI Cochrane Colloquium. Barcelona; 2003 [http://www.hrc.es/investigacion/metadisc. $h \mathrm{html].}$

31. Review Manager (RevMan) [Computer program]. Version 4.2 for Windows. Oxford, England: The Cochrane Collaboration; 2002.

32. Bachman JW, Heise RH, Naessens JM, Timmerman MG: A study of various tests to detect asymptomatic urinary tract infections in an obstetric population. JAMA 1993, 270(16):1971-1974.

33. Bailey BL Jr: Urinalysis predictive of urine culture results. J Fam Pract 1995, 40(1):45-50.

34. Barry $\mathrm{HC}$, Ebell $\mathrm{MH}$, Hickner J: Evaluation of suspected urinary tract infection in ambulatory women: a cost-utility analysis of office-based strategies. J Fam Pract 1997, 44(1):49-60.

35. Bergus GR, Chapman GB, Levy BT, Ely JW, Oppliger RA: Clinical diagnosis and the order of information. Med Decis Making 1998, 18(4):412-417.

36. Dove GA, Bailey AJ, Gower PE, Roberts AP, De Wardener HE: Diagnosis of urinary-tract infection in general practice. Lancet 1972, 2(7790):1281-1283.

37. Grob PR, Manners BT, Dulake C: A survey of urinary-tract infection in a general practice. Practitioner 1970, 204(222):567-574.

38. Gulich M, Bux C, Zeitler HP: The guideline "Dysuria" by the German Society of General Practice and Family Medicine (DEGAM) - Possible consequences of the implementation in general practice. $Z$ Arztl Fortbild Qual Sich 2001, 95(2):141-145.

39. Hiller L, Radley S, Mann CH, Radley SC, Begum G, Pretlove SJ, Salaman JH: Development and validation of a questionnaire for the assessment of bowel and lower urinary tract symptoms in women. BJOG 2002 , 109(4):413-423.

40. Hiller L, Bradshaw HD, Radley SC, Radley SA: Scoring system for the assessment of bowel and lower urinary tract symptoms in women. BJOG 2002, 109(4):424-430

41. Jordan S, Wilcox GM, Wasson JH: Urinary tract infection in women visiting rural primary care practices. J Fam Pract 1982, 15(3):427-429.

42. Komaroff AL, Pass TM, McCue JD, Cohen AB, Hendricks TM, Friedland G: Management strategies for urinary and vaginal infections. Arch Intern Med 1978, 138(7):1069-1073.

43. Moore KN, Murray S, Malone-Lee J, Wagg A: Rapid urinalysis assays for the diagnosis of urinary tract infection. Br J Nurs 2001, 10(15):995-1001.

44. Ruttimann S, Clemencon D: Usefulness of routine urine analysis in medical outpatients. J Med Screen 1994, 1(2):84-87.

45. McNulty CA, Bowen J, Clark G, Charlett A, Cartwright K, South West G, Microbiology Laboratory Use Group: How should general practitioners investigate suspected urinary tract infecton? Variatins in laboratoryconfirmed bacteriuria in South West England. Commun dis Public Health 2004, 7(3):220-226

46. Andre M, Molstad S, Lundborg CS, Odenholt I, Swedish Study Group on Antibiotic Use: Management of urinary tract infections in primary care: a repeated 1-week diagnosis-prescribing study in five counties in Sweden in 2000 and 2002. Scan J Infect dis 2004, 36(2):134-138.

47. Winkens $\mathrm{R}$, Nelissen-Arets $\mathrm{H}$, Stobberingh $\mathrm{E}$ : Validity of the urine dipslide under daily practice conditions. Fam Pract 2003, 20(4):410-412.

48. Bosisio V, Stella R, Castagna S, Marchetti F: A prospective, descriptive study on the practice of management of urinary tract infections by general practitioners in Italy: clinical pathways (part II). Arch Ital Urol Androl 2003, 75(2):93-98.

49. Bosisio V, Stella R, Castagna S, Marchetti F: A prospective, descriptive study on the practice of management of urinary tract infections by general practitioners in Italy: epidemiology (part I). Arch Ital Urol Androl 2003, 75(2):88-92.
50. McNulty C, Freeman E, Nichols T, Kalima O: Laboratory diagnosis of urinary symptoms in primary care - a qualitative study. Commun Dis Public Health 2003, 6(1):44-50.

51. Flach SD, Longenecker JC, Tape TG, Bryan TJ, Parenti C, Wigton RS: The relationship between treatment objectives and practice patterns in the management of urinary tract infections. Med Decis Making 2003, 23(2):131-139.

52. Flottorp S, Oxman AD, Havelsrud K, Treweek S, Herrin J: Cluster randomised controlled trial of tailored interventions to improve the management of urinary tract infections in women and sore throat. $B M J$ 2002, 325(7360):367-370.

53. Ferry SA, Holm SE, Stenlund H, Lundholm R, Monsen TJ: The natural course of uncomplicated lower urinary tract infection in women illustrated by a randomized placebo controlled study. Scand I Infect Dis 2004, 36(4):296-301.

54. Car J, Svab I, Kersnik J, Vegnuti M: Management of lower urinary tract infection in women by Slovene GPs. Fam Pract 2003, 20(4):452-456.

55. Canbaz S, Peksen YU, Sunter AT, Leblebicioglu H, Sunbul M: Antibiotic prescribing and urinary tract infection. Int J Antimicrob Agents 2002, 20(6):407-411

56. Little P, Turner S, Rumsby K, Warner G, Moore M, Lowes JA, Smith H, Hawke C, Mullee M: Developing clinical rules to predict urinary tract infection in primary care settings: sensitivity and specificity of near patient tests (dipsticks) and clinical scores. Br J Gen Pract 2006, 56(529):606-612.

57. Okamura K, Hasegawa T, Nojiri Y, Kobayashi M, Murase T, Yanagihara T, Okamoto I: Diagnosis and treatment of lower urinary tract symptoms in the elderly by general practitioner. Geriatr Gerontol Int 2008, 8(2):119-125.

58. Nørby B, Dørflinger T: Investigation of lower urinary tract symptoms among men in general practice and in hospitals. Ugeskr Laeger 2007, 169(20):1923-1925.

59. Haab F, Costa P, Colau JC, Gérard A, Liard F, Bohbot JM, Leng JJ, Lobel B, Soussy CJ, Boulanger P: Management of urinary tract infections in women. Epidemiologic survey of 7916 women in general practice. Presse Med 2006, 35(9 Pt1):1235-1240.

60. Brumfitt W, Hamilton-Miller JM: The appropriate use of diagnostic services: (XII). Investigation of urinary infections in general practice: are we wasting facilities? Health Bull (Edinb) 1987, 45(1):5-10.

61. Culhane JK: Clinical uses of the leukocyte esterase test. Prim Care 1986, 13(4):679-689.

62. Farrar WE Jr: Infections of the urinary tract. Med Clin North Am 1983, 67(1):187-201.

63. Hovig B: Urinary tract infections. Recommendations with special emphasis on family practice. Tidsskr Nor Laegeforen 1993, 113(1):44-46.

64. Jefferys A, Suranyi M, Pokorny CS: The detection and investigation of pyuria. Med Today 2002, 3(5):63-66.

65. Kunin CM, Urinary tract infections: Flow charts (algorithms) for detection and treatment. JAMA 1975, 233(5):458-462.

66. Probst W: Urinary tract infections in general practice. Ther Umsch 1992, 49(4):239-244

67. Deville WL, Yzermans JC, van Duijn NP, Bezemer PD, van der Windt DA, Bouter LM: The urine dipstick test useful ro rule out infections. A metaanalysis of the accuracy. BMC Urol 2004, 4(1):4.

68. Rothberg MB, Wong JB: All dysuria is local. A cost-effectiveness model for designing site-specific management algorithms. J Gen Intern Med 2004, 19(5 Pt 1):433-443.

69. Hummers-Pradier $\mathrm{E}$, Kochen MM: Urinary tract infections in adult general practice patients. Br J Gen Pract 2002, 52(482):752-761.

70. Car J, Urinary tract infections in women: Diagnosis and management in primary care. Br Med J 2006, 332(7533):94-97.

71. Acute uncomplicated urinary tract infection in women. MeReC Bull 2006, 17(3):18-20.

72. Drekonja DM, Johnson JR: Urinary Tract Infections. Prim Care Clin Off Pract 2008, 35(2):345-367.

73. Olesen F, Oestergaard I: Patients with urinary tract infection: proposed management strategies of general practitioners, microbiologists and urologists. Br J Gen Pract 1995, 45(400):611-613.

74. Urinary tract infection in general practice. J $R$ Coll Gen Pract 1973, 23(133):529-530 
75. Meijman FJ: The Dutch College of General Practitioners' guideline on urinary tract infections: response from the viewpoint of family practice. Ned Tijdschr Geneeskd 2001, 145(15):716-717.

76. Pastor Molas FJ, Torrente Gonzalez N, Guarro Artigas J, Soler Alcon L: Rapid diagnostic methods as predictors of urinary infection in primary care. Med Clin (Barc) 1989, 93(3):118-119.

77. Wright OR, Safranek S: Urine dipstick for diagnosing urinary tract infection. Am Fam Phys 2006, 73(1):129-131.

78. Desgrandchamps F: Urinary tract infections in women. Presse Med 2006, 35(9 Pt 1):1207-1208

79. Mangin D, Toop L: Urinary tract infection in primary care. BMJ 2007, 334(7594):597-598

80. Scheibe $\mathrm{H}$ : Uncomplicated urinary tract infections. With the anamnesis it is not done. MMW Fortschr Med 2008, 150(3-4):7.

81. Goolsby MJ: Urinary tract infection. J Am Acad Nurse Pract 2001, 13(9):395-398.

82. Houston M: Uncomplicated urinary tract infection in women. Diagnostic and therapeutic recommendations by the Institute for Clinical Systems Integration. Postgrad Med 1999, 105(5):181-183, 187-188.

83. Berg AO, Heidrich FE, Fihn SD, Bergman JJ, Wood RW, Stamm WE, Holmes KK: Establishing the cause of genitourinary symptoms in women in a family practice. Comparison of clinical examination and comprehensive microbiology. JAMA 1984, 251(5):620-625.

84. O'Dowd TC, Smail JE, West RR: Clinical judgment in the diagnosis and management of frequency and dysuria in general practice. Br Med J (Clin Res Ed) 1984, 288(6427):1347-1349.

85. Mclsaac WJ, Prakash P, Ross S: The management of acute uncomplicated cystitis in adult women by family physicians in Canada. Can J Infect Dis Med Microbiol 2008, 19(4):287-293.

86. Maestra Onteniente A, Vazquez Garcia B, Duran Luceno MC, GarciaArquimbau Ayuso M, Ruiz De Adana Perez R, Arco Montejo J: Utility of dipstick tests for the diagnosis of non complicated urinary tract infections. Medifam Rev Med Fam Comunitaria 2000, 10(6):345-350.

87. Mond NC, Percival A, Williams JD, Brumfitt W: Presentation, diagnosis, and treatment of urinary tract infections in general practice. Lancet 1965 , 1:514-516.

88. Peddie BA, Little PJ, Sincock AR: Urinary tract infection in general practice. N Z Med 1978, 88(622):317-320.

89. Buzayan MM, Tobgi RS: Comparison of urine culture, microscopy and nitrite dipstick tests in the detection of urinary tract infection. J Bahrain Med Soc 2008, 20(3):124-127.

90. Hummers-Pradier E, Ohse AM, Koch M, Heixmann WR, Kochen MM: Management of urinary tract infections in female general practice patients. Fam Practice 2005, 22:71-77.

91. Nys S, van Merode T, Bartelds AIM, Stobberingh EE: Urinary tract infections in general practice patients: Diagnostic tests versus bacteriological culture. J Antimicrob Chemother 2006, 57(5):955-958.

92. Knottnerus BJ, Bindels PJE, Geerlings SE, Van Charante EPM, Ter Riet G: Optimizing the diagnostic work-up of acute uncomplicated urinary tract infections. BMC Fam Pract 2008, 9.

93. Deeks JJ: Systematic reviews of evaluations of diagnostic and screning test. In BMJ Publishing Group. London.. 2 edition. Edited by: Egger M, Smith GD, Altman DG. Systematic Reviews in Health Care. Metaanalysis en context; 2003:.

94. Richardson WS, Wilson M, Williams J, Moyer V, Naylor D: Diagnosis. Clinical Manifestations of Disease.Edited by: Guyatt G, Rennie D. User's Guides to the Medical Literature. A Manual for Evidence Based Clinical Practice. JAMA and Archives Journals; 2002:, American Medical Association.

95. Knottnerus JA: Diagnostic prediction rules: principles, requirements, and pitfalls. Prim Care 1995, 22(2):341-363.

96. Lachs MS, Nachamkin I, Edelstein PH, Goldman J, Feinstein AR, Schwartz S: Spectrum Bias in the Rapid Dipstick Test for Urinary Tract Infection. Ann Intern Med 1992, 117(2):135-140.

97. Sackett DL, Haynes RB, Tugwell P: Clinical Epidemiology: Basic Science for Clinical Medicine. Epidemiologia Clínica. Una ciencia básica para la medicina clínica. Ed Ediciones Díaz de Santos SA. Madrid; 1989.

98. Knowles DR, Dysuria: U.S. National Library of Medicine and the National Institutes of Health. Medical Encyclopedia 2002 [http://www.nlm.nih.gov/ medlineplus/ency/article/003145.htm], Last updated: 8/10/2003.

99. Ho KMT, Mammen KJ, Fellows GJ: Definition of dysuria. B J Urol 1994 74:533-544.
100. Pinnock CB, Marshall VR: Troublesome lower urinary tract symptoms in the community: a prevalence study. MJA 1997, 167:72-75.

101. Jolleys JV: Factors associated with regular episodes of dysura among women in one rural general practice. B J Gen Practice 1991, 41:241-243.

102. Moller LA, Lose $G$, Jorgesen $T$ : Incidence and remission rates of lower urinary tract symptoms at one year in women aged 40-60: longitudinal study. BMJ 2000, 320:1429-1432.

103. Whiting PF, Weswood ME, Rutjes AW, Reitsma JB, Bossuyt PN, Kleijnen J: Evaluation of QUADAS, a tool for the quality assessment of diagnostic accuracy studies. BMC Med Res Methodol 2006, 6:9.

104. Ransohoff DF, Feinstein AR: Problems of spectrum and bias in evaluating the efficacy of diagnostic test. N Engl J Med 1978, 199:936-930.

105. Montori V, Guyatt G: Summarizing the evidence. Publication Bias. In JAMA and Archives Journals. Edited by: Guyatt G, Rennie D. User's Guides to the Medical Literature. A Manual for Evidence Based Clinical Practice; 2002:, American Medical Association,

106. Egger M, Dickersin K, Smith GD: Problems and limitations in conducting systematic reviews. In BMJ Publishing Group. London.. 2 edition. Edited by: Egger M, Smith GD, Altman DG. Systematic Reviews in Health Care. Metaanalysis en context; 2003:

\section{Pre-publication history}

The pre-publication history for this paper can be accessed here: http://www.biomedcentral.com/1471-2296/12/111/prepub

\section{doi:10.1186/1471-2296-12-111}

Cite this article as: Medina-Bombardó and Jover-Palmer: Does clinical examination aid in the diagnosis of urinary tract infections in women? A systematic review and meta-analysis. BMC Family Practice 2011 12:111.

\section{Submit your next manuscript to BioMed Central and take full advantage of:}

- Convenient online submission

- Thorough peer review

- No space constraints or color figure charges

- Immediate publication on acceptance

- Inclusion in PubMed, CAS, Scopus and Google Scholar

- Research which is freely available for redistribution 